\title{
Sifat Tarik dan Struktur Mikro Sambungan Las Gesek Tak Sejenis Baja-Tembaga
}

(Tensile Properties and Microstructure of Dissimilar Friction Welded Joint between SteelCooper)

\author{
Ady Ryan Romadhan ${ }^{a}$, Aris Widyo Nugroho ${ }^{* b}$, Totok Suwanda ${ }^{c}$, Romi Wilza $^{d}$ \\ ${ }_{a, b, c}$ Program Studi Teknik Mesin, Universitas Muhammadiyah Yogyakarta \\ Jalan Brawijaya, Tamantirto, Kasihan, Bantul, DI Y, Indonesia, 55183 \\ Telepon/Fax: (0274) 387656/387646 \\ e-mail: ady.ryan.2014@ft.umy.ac.id,nugrohoaris@gmail.com*,t_suwanda@yahoo.com

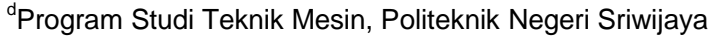 \\ Jl. Srijaya Negara Bukit Besar, Palembang, Sumatera Selatan Indonesia 30139 \\ Telepon : 62711353414 Fax : 62711355918 \\ e-mail: romi_wilza@yahoo.com
}

\begin{abstract}
Abstrak
Tembaga dikenal memilki keunggulan sifat fisis sehingga sering diaplikasikan bersamaan dengan baja menggunakan teknik brazing yang membutuhkan filler. Friction welding memberikan alternatif penyambungan tak sejenis tanpa filler dan asap. Penelitian ini dilakukan untuk mengetahui efek tekanan gesek terhadap sifat mekanis sambungan las gesek pada sambungan dissimilar baja-tembaga. Silinder tembaga dan baja dibubut menjadi bentuk setengah bagian dari benda uji standar JIS Z 2201. Proses pengelasan dilakukan pada putaran $1000 \mathrm{rpm}$ dengan variasi tekanan gesek sebesar 30, 35, dan 40 $\mathrm{MPa}$ dengan tekanan tempa $80 \mathrm{MPa}$. Waktu gesek dan waktu tempa masingmasing 5 detik. Hasil penyambungan masing-masing diamati struktur mikro, kekerasan dan sifat tariknya. Hasil penelitian menunjukkan bahwa dengan meningkatnya tekanan gesek maka daerah TMAZ melebar. Struktur mikro berbutir halus teramati di bagian baja, sedangkan di daerah tembaga, orientasi butir berubah memanjang searah dengan permukaan sambungan. Pada daerah termomechanically affected zone (TMAZ) dan welding center zone (WCZ) kekerasan masing-masing logam turun seiring dengan kenaikan tekanan gesek. Lebar daerah TMAZ yang cukup membuat kekuatan tarik tertinggi diperoleh dari spesimen dengan variasi $35 \mathrm{MPa}$ sebesar $89 \mathrm{MPa}$. Metode las ini dapat digunakan untuk penyambungan logam tak sejenis baja-tembaga dengan memperhitungkan luasan daerah TMAZ.
\end{abstract}

Kata Kunci: Friction welding, sambungan logam dissimilar, tekanan gesek, $T M A Z$

\section{Abstract}

Copper is often used along with steel due to it excellence properties by using brazing technique. Friction welding technique offers an alternative technique for joining dissimilar metal without fillers and smoke. This research purpose is to study the effect of the friction pressure on the mechanical properties of steel-cooper friction welded joints. Copper and steel bars were turned into half the shape of the specimen according to JIS Z 2201. The welding process was carried out at a speed of $1000 \mathrm{rpm}$ with the friction pressures of 30, 35, and 40 $\mathrm{MPa}$ under an upset stress of $80 \mathrm{MPa}$ for 5 seconds of friction time and upset time. The results showed that with increasing friction pressure the TMAZ area was widened in fine grained microstructure for the steel region. Whereas in the copper region, the orientation of elongated grains inline with the direction of the joining surface. In the TMAZ and WCZ areas the hardness of each metal decreases with increasing friction pressure. The sufficient width of the TMAZ results in the highest tensile strength of $89 \mathrm{MPa}$. It was obtained from the specimens with friction pressure of $35 \mathrm{MPa}$. This welding method is potentially used for dissimilar steel-copper joint by considering the area of the TMAZ region.

Keywords: Friction welding, dissimilar metals joint, pressure friction, TMAZ 


\section{Pendahuluan}

Logam non fero seperti paduan alumunium, paduan magnesium, paduan tembaga dan paduan titanium telah menarik perhatian dalam banyak aplikasi karena kelebihan di sifat fisis dan sifat kimianya. Penyambungan logam dissimilar banyak dikembangkan dan diaplikasikan di berbagai industri [1]. Hal itu terjadi karena sambungan dissimilar dapat menghasilkan kombinasi yang menarik baik dari segi struktur maupun sifat-sifat fungsionalnya, sehingga menawarkan banyak keuntungan teknik dan ekonomis [2]. Namun, penyambungan logam berbeda jenis (dissimilar) mempunyai kesulitan karena perbedaan sifat termal, fisik, metalurgi, dan mekanik dari logam yang akan disambung [3], sehingga sulit untuk dilakukan penyambungan dengan teknik pengelasan lebur (fusi). Pengelasan gesek dilakukan tidak melalui fase lebur sehingga dapat dikembangkan untuk penyambungan dissimilar logam. Dalam pengelasan gesek, penyambungan antar logam terjadi karena adanya difusi antar muka logam akibat panas yang dihasilkan dari konversi energi mekanik menjadi energi panas pada antarmuka benda kerja selama bergesekan secara rotasi, yang dilanjutkan dengan pemberian upset strees selama waktu tertentu (upset time).

Beberapa penelitian tentang sambungan dissimilar logam fero-non fero, seperti sambungan baja-paduan alumunium [4,5], baja tahan karat-paduan alumunium $[6,7,8]$ telah berhasil dilakukan. Struktur logam fero-paduan alumunium banyak diaplikasikan karena dapat menurunkan bobot dari struktur [9]. Selain itu juga banyak dikembangkan sambungan dissimilar logam fero-paduan tembaga agar memperoleh struktur yang kuat dan berkonduktivitas listrik dan panas yang tinggi. Beberapa penelitian yang telah dilakukan meliputi sambungan dissimilar baja-tembaga [10,11,12], baja-paduan tembaga [13,14], dan baja tahan karat- tembaga [15,16]. Jayabharath dkk. [11] menyambung silinder baja dari proses metalurgi serbuk dengan silinder tembaga menggunakan las gesek putaran konstan $1500 \mathrm{rpm}$ pada berbagai variasi densitas dari silinder baja, tekanan gesek dan tekanan upsetnya. Sambungan pada silinder dengan densitas silinder baja lebih rendah dengan parameter proses yang lebih rendah memberikan sifat-sifat sambungan yang lebih tinggi dibandingkan sambungan pada baja densitas tinggi dengan parameter proses yang lebih tinggi. Sedangkan kekerasan di daerah sambungan las baik di bagian tengah maupun di bagian pinggir sambungan terukur meningkat dibanding material dasarnya karena adanya peningkatan densitas akibat penempaan pada proses pengelasan. Namun penelitian ini belum mengukur efisiensi dari sambungan. Kimura, dkk [10] meneliti lebih detil pengaruh proses paramater pengelasan (tekanan pengelasan) pada kecepatan putar $1650 \mathrm{rpm}$, terhadap fenomena proses penyambungan (temperatur dan torsi gesek) dan sifat mekanis (kekerasan dan kekuatan tarik) sambungan disimilar baja karbon rendah dengan tembaga yang dihasilkan. Hasil penelitian menunjukkan bahwa secara umum temperatur di bagian tengah sambungan (center) silinder lebih rendah dibanding bagian tepi silinder. Temperatur yang lebih tinggi $\left(700^{\circ} \mathrm{C}\right)$ dan waktu gesek yang lebih lama (2.8 detik). dicapai pada sambungan dengan tekanan gesek $30 \mathrm{MPa}$ karena torsi gesek yang dihasilkan lebih rendah $(20 \mathrm{Nm})$. Sedangkan pada tekanan gesek $90 \mathrm{MPa}$ menimbulkan torsi gesek yang lebih tinggi $(40 \mathrm{Nm}$ ), sehingga mampu menghasilkan waktu gesek lebih pendek (1.2 detik) dan suhu gesek yang lebih rendah $\left(600^{\circ} \mathrm{C}\right)$. Efisiensi sambungan pada tekanan upset $30 \mathrm{MPa}$ dapat mencapai $40 \%$ pada tekanan gesek $30 \mathrm{MPa}$, sedangkan pada sambungan dengan tekanan gesek $90 \mathrm{MPa}$ dan tekanan upset $90 \mathrm{MPa}$ dapat mencapai efisiensi $80 \%$. Kekerasan sambungan di bagian baja meningkat, namun kekerasan di bagian tembaga teramati menurun. Sifat mekanis, efisiensi mencapai $80 \%$ juga disajikan oleh penelitian yang dilakukan oleh Wei dan Sun [12] pada kecepatan putar $1950 \mathrm{rpm}$ dan tekanan gesek $36 \mathrm{MPa}$. Penelitian di atas menggunakan kecepatan putar sedang dan tinggi, sedangkan pengelasan dengan putaran rendah belum banyak dilakukan.

Penelitian ini bertujuan untuk mengetahui pengaruh besar gaya gesek terhadap struktur mikro dan sifat mekanis dari sambungan las pada kecepatan putar pengelasan rendah, 1000 rpm. Kekerasan di daerah sambungan diukur dengan mikrohardness test, kekuatan tarik dari masing-masing sambungan juga dievaluasi. 


\section{Metode}

\subsection{Poses Pengelasan}

Sebelum dilakukan pengelasan bahan harus dipotong dengan panjang masing-masing $75 \mathrm{~mm}$ kecuali untuk benda kerja tembaga yang akan dilas pada variasi tekanan gesek 40 MPa panjangnya $85 \mathrm{~mm}$. Setelah dipotong maka ratakan permukaan yang akan disambung melalui proses pemesinan yaitu bubut. Selanjutnya melakukan kalibrasi pada mesin las gesek dengan tujuan untuk mendapatkan hasil pengujian yang sesuai dengan parameter yang telah ditentukan. Kalibrasi mesin las gesek ini dilakukan dengan cara mengatur tekanan dengan mesin hidrolik menggunakan Load cell. Pengaturan ini bertujuan untuk mengetahui seberapa besar tekanan setiap dilakukan pembukaan katup secara bervariasi.

Proses pengelasan menggunakan parameter tekanan gesek dengan variasi 30,35 , dan $40 \mathrm{MPa}$. Putaran mesin tetap dijaga konstan yaitu $1000 \mathrm{rpm}$ menggunakan tekanan tempa $80 \mathrm{MPa}$ dengan masing-masing waktu tempa dan gesek adalah 5 detik. Pengelasan gesek dilakukan sebanyak 4 kali pada masing-masing variasi spesimen. Bahan yang digunakan dalam penelitian ini adalah silinder pejal tembaga dan baja dengan masing-masing diameter $12.7 \mathrm{~mm}$.

Selanjutnya pengelasan gesek dilakukan dengan memasangkan benda kerja pada cekam, baja pada cekam yang berputar dan tembaga pada cekam yang diam. Pada masingmasing permukaan sebisa mungkin harus rata atau presisi (gambar 2.1). Setelah mesin dihidupkan, tarik tuas hidrolik hingga benda kerja bergesekan dengan durasi 5 detik. Tekanan tempa diberikan selama 5 detik setelah gesekan berhenti.

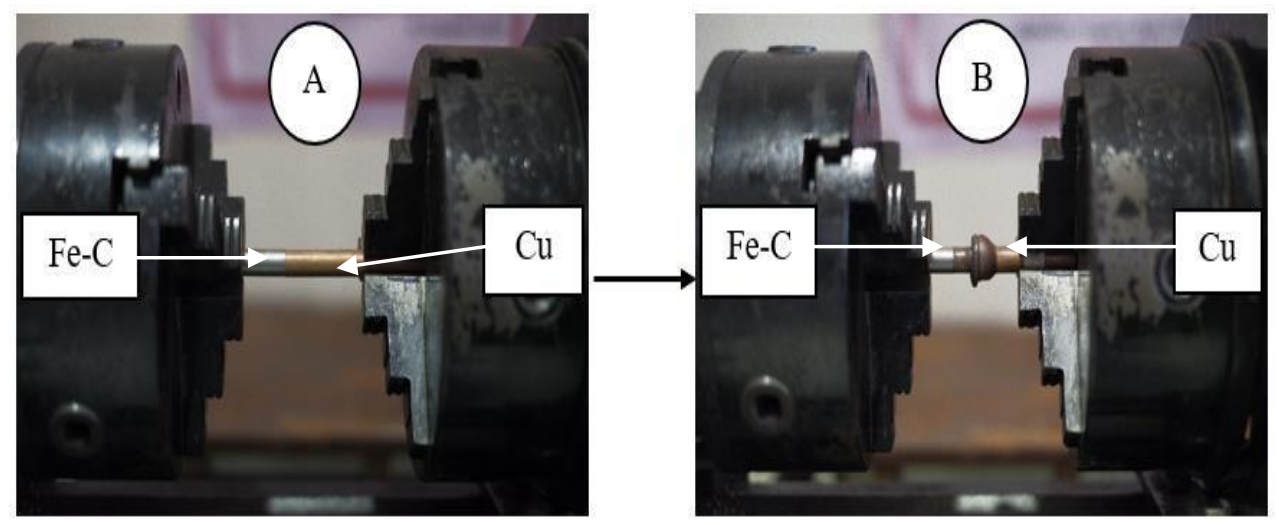

Gambar 2.1 Proses pengelasan gesek dissimilar silinder pejal baja-tembaga, (A) sebelum pengelasan, (B) sesudah pengelasan

\subsection{Pengamatan Struktur Mikro}

Pengujian struktur mikro dilakukan untuk melihat perubahan struktur mikro pada benda kerja setelah dilakukan pengelasan. Pengujian menggunakan mikroskop dengan 200x perbesaran. Benda uji yang telah tersambung dipotong dan dibelah menjadi 2 bagian menggunakan gergaji besi untuk pengujian struktur mikro dan kekerasan. Spesimen yang sudah dibelah kemudian dicetak dengan resin. Selanjutnya dilakukan pengamplasan menggunakan mesin amplas menggunakan nomer amplas 120, 320, 800, 1000, 1500, 2000 secara berurutan agar permukaan pada benda uji benar-benar halus. Selanjutnya dilakukan pemolesan menggunakan pasta autosol secukupnya untuk persiapan pengetsaan. Proses pengetsaan menggunakan larutan kimia $\mathrm{HNO} 365 \%$ + Alkohol. Pengujian dilakukan dengan menggunakan mikroskop optik Olympus tipe PME3. 

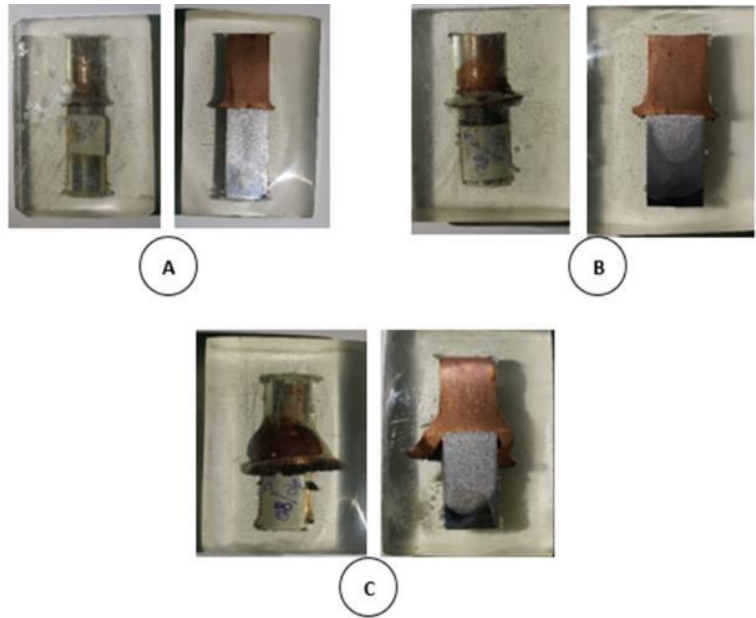

Gambar 2.2 Hasil mounting spesimen uji: (A) $30 \mathrm{MPa},(B) 35 \mathrm{MPa},(C) 40 \mathrm{MPa}$

\subsection{Pengujian Kekerasan}

Pengujian kekerasan pada penelitian ini menggunakan alat uji kekerasan micro vickers dengan pembebanan 200 gf. Pengujian kekerasan dilakukan untuk mengetahui nilai kekerasan pada spesimen hasil pengelasan gesek tiap variasi tekanan gesek. Pada pengujian kekerasan ini, posisi titik pengujian untuk pengambilan data pada spesimen ada 12 titik pengujian. Posisi titik pengujian kekerasan dimulai dari titik 0,$05 ; 0,5 ; 1,5 ; 3 ; 6 ; 8$ pada tembaga dari titik sambungan dan 0,$05 ; 0,5 ; 1 ; 1,5 ; 3 ; 5$ pada baja dari titik sambungan. Posisi titik pengujian dapat dilihat pada gambar 2.3.

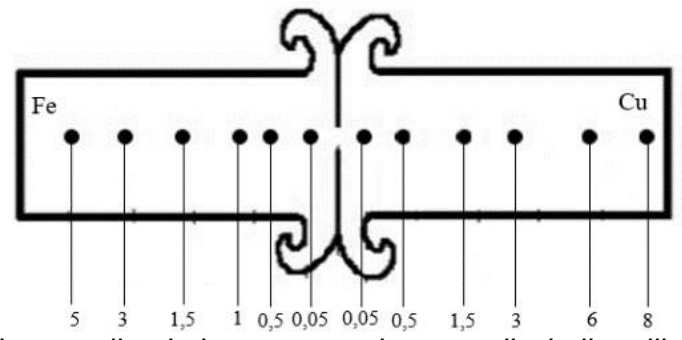

Gambar 2.3 Posisi titik pengujian kekerasan sambungan dissimilar silinder pejal baja-tembaga

\subsection{Pengujian Tarik}

Pengujian tarik pada penelitian ini dilakukan menggunakan mesin uji tarik Universal Testing Machine (UTM). Pengujian tarik ini dilakukan pada masing-masing spesimen variasi tekanan gesek sebanyak 3 buah. Sebelum melakukan pengujian tarik, spesimen uji tarik dilakukan proses pemesinan untuk menghilangkan flash pada daerah sambungan dan dibentuk sesuai standar JIS Z 2201.

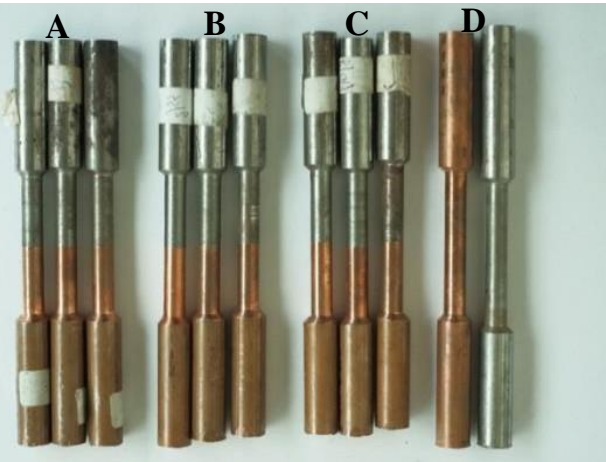

Gambar 2.4 Spesimen uji tarik(A) 30 MPa, (B) $35 \mathrm{MPa}$, (C) $40 \mathrm{MPa}$, dan (D) baja dan tembaga 


\section{Hasil dan Pembahasan}

\subsection{Hasil Sambungan Las Gesek Dissimilar Silinder Pejal Tembaga-Baja}

Hasil pengelasan gesek dissimilar silinder pejal tembaga-baja beserta grafik hubungan pemendekan dengan tekanan gesek ditunjukkan oleh Gambar 3.1. Dengan meningkatnya tekanan gesek maka flash yang dihasilkan semakin lebar dan pemendekan juga semakin besar. Hal ini kemungkinan disebabkan oleh durasi gesekan yang relatif lama yaitu 5 detik. Semakin lama waktu gesekan maka suhu yang diperoleh akibat gesekan juga semakin tinggi. Deformasi tinggi (flash) teramati pada daerah lasan tembaga karena flow stress yang rendah dan konduktifitas panas yang tinggi [11]. .

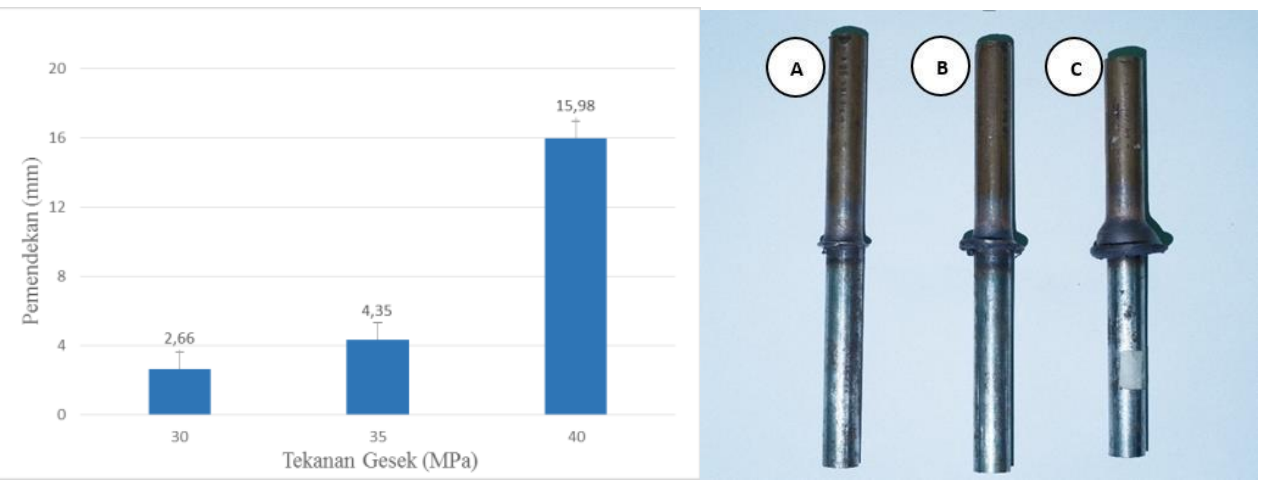

Gambar 3.1 Hasil pengelasan dengan tekanan gesek: (A) $30 \mathrm{MPa}$, (B) $35 \mathrm{MPa},(C) 40 \mathrm{MPa}$ dan (D) grafik hubungan pemendekan dengan tekanan gesek

\subsection{Hasil Pengamatan Struktur Mikro}

Hasil pengamatan struktur mikro dari sambungan lasan ditunjukkan oleh Gambar 3.2 dimana teramati adanya perubahan struktur mikro pada tembaga-baja setelah dilas gesek. Pada daerah welding center zone (WCZ) baja terjadi pengecilan butir yang semakin meluas dengan naiknya tekanan gesek. Hal ini mungkin disebabkan karena semakin tinggi tekanan gesek maka temperaturnya akan semakin tinggi, sehingga ketika temperatur mencapai titik di atas rekristalisasi akan merubah bentuk struktur mikro dari baja. Lalu, semakin tinggi temperaturnya maka butiran yang berubah semakin meluas. Pada material baja tidak ditemukan heat affected zone (HAZ) karena temperatur pada saat gesekan tidak cukup untuk membentuk HAZ pada baja.

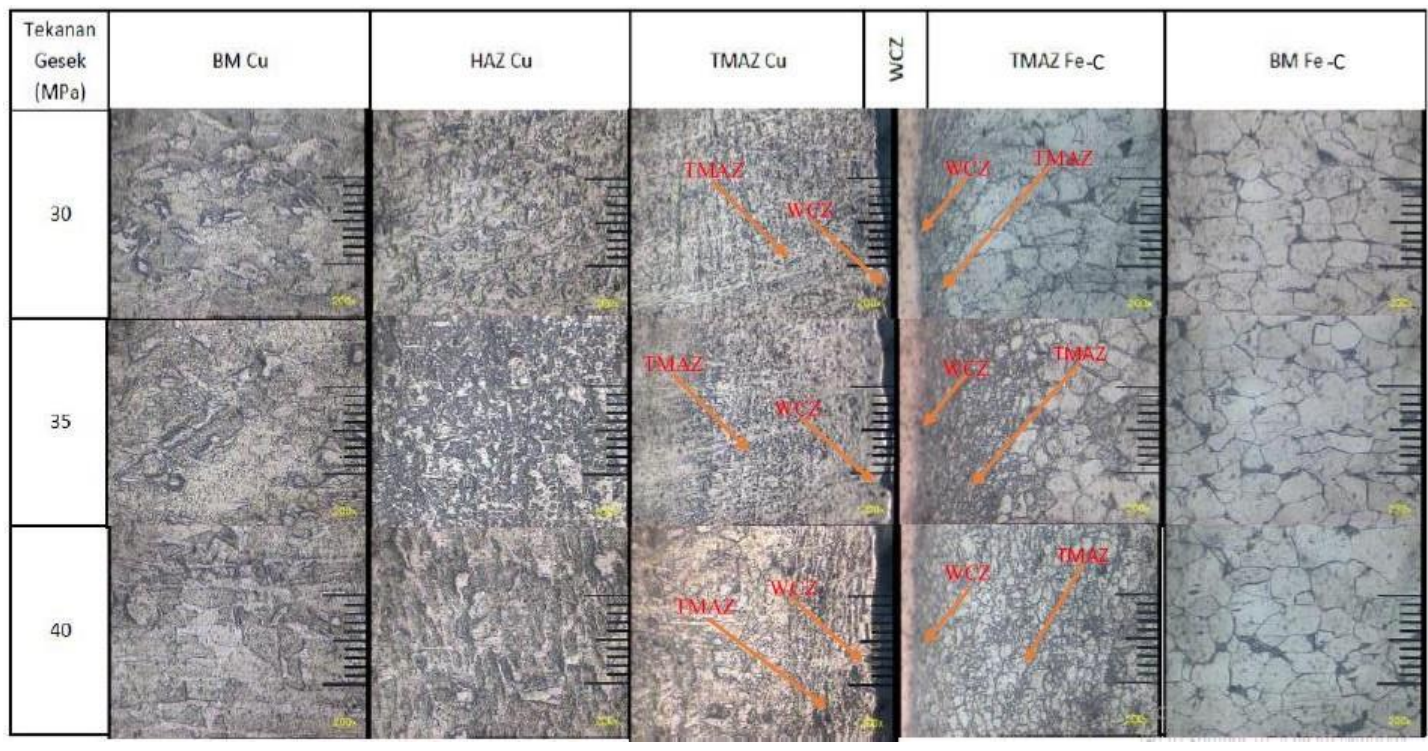

Gambar 3.2 Foto struktur mikro pengelasan gesek silinder pejal tembaga-baja 
Struktur mikro di daerah thermomechanically affected zone (TMAZ) dan HAZ pada spesimen tembaga variasi tekanan $30 \mathrm{MPa}$ ke $35 \mathrm{MPa}$ tidak mengalami perubahan yang signifikan. Tetapi pada spesimen dengan tekanan gesek $40 \mathrm{MPa}$ daerah WCZ butirnya lebih besar dan mengalami kepadatan. Lalu daerah TMAZ butirnya besar hampir sama dengan daerah HAZ. Karena pada tekanan $40 \mathrm{MPa}$ temperatur dari gesekan tinggi sehingga deformasi plastis juga tinggi dan pengaruh tekanan tempa sebesar 80 . Sehingga pada bagian interface tembaga yang deformasi plastisnya tinggi membentuk flash yang berlebih dan mengakibatkan kepadatan struktur mikro pada interface tembaga. Daerah HAZ tembaga struktur mikronya hampir sama dengan basemetal. Penambahan tekanan menyebabkan peningkatan ukuran butir butiran HAZ pada tembaga.

\subsection{Hasil Pengujian Kekerasan}

Setelah pengujian struktur mikro dilakukan maka dapat diketahui posisi untuk menentukan titik pengujian kekerasan. Spesimen yang digunakan untuk pengujian kekerasan adalah hasil sambungan dengan variasi tekanan gesek 30, 35, dan $40 \mathrm{MPa}$. Pengujian kekerasan ini menggunakan metode uji Vickers dengan pembebanan $200 \mathrm{gf}$. Hasil pengujian kekerasan ditunjukkan pada Gambar 3.3.

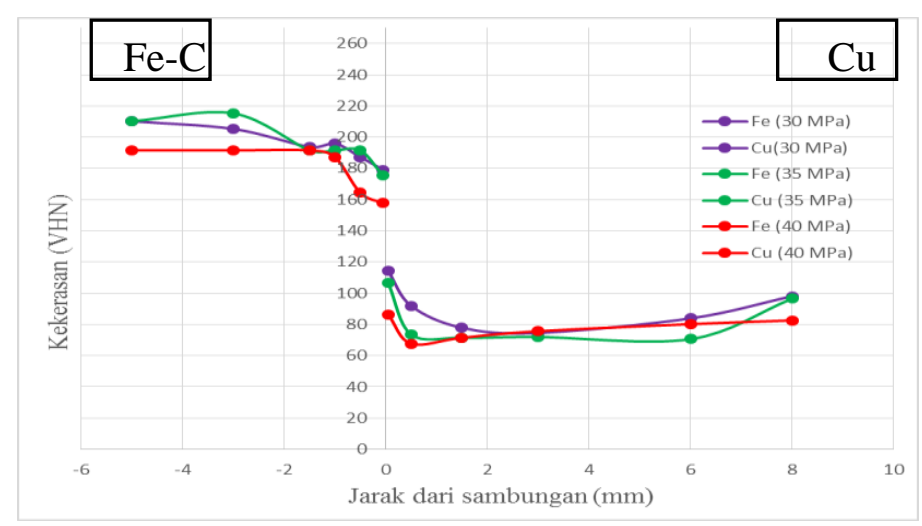

Gambar 3.3 Grafik nilai kekerasan pada sambungan dissimilar silinder pejal baja-tembaga

Gambar tersebut menunjukkan nilai kekerasan setiap sambungan las ada masingmasing variasi tekanan gesek. Semakin tinggi nilai tekanan gesek, waktu untuk mencapai temperatur thermomechanically plastic semakin pendek, sedangkan waktu gesek diatur 5 detik, sehingga durasinya berlangsung lebih lama yang mengakibatkan daerah berbutir kecil tersebut menjadi semakin melebar. Dengan temperatur tinggi pada proses penyambungan yang lebih lama maka kekerasan menjadi semakin menurun. Hal ini menunjukkan bahwa efek termal akibat friction welding menurunkan kekerasan material yang di las dibandingkan dengan logam dasarnya [8].

\subsection{Hasil Pengujian Tarik}

Diagram tegangan-regangan hasil pengujian tarik ditunjukan pada Gambar 3.4. Gambar tersebut menunjukkan hubungan antara kekuatan tarik dengan regangan setelah dilakukan uji tarik. Baja dan tembaga menunjukkan perilaku material dengan sifat yang ulet, dimana keuletan baja lebih tinggi dibanding baja. Hal ini disebabkan oleh sifat inheren dari tembaga yang berstruktur kristal FCC sedangkan baja berstruktur BCC. Daerah plastis dari tembaga lebih lebar dari baja. Namun kekuatan baja (226.3 MPa) jauh lebih tinggi dari tembaga (112.5 MPa). Pada logam dengan sambungan dissimilar menunjukkan perilaku patah getas dimana tidak terlihat adanya daerah plastis. Namun regangan patah terlihat meningkat seiring kenaikan tekanan gesek. Kekuatan tarik maksimum dari sambungan (tekanan gesek $35 \mathrm{MPa}$ ) mendekati kekuatan tarik dari tembaga. Hal ini menunjukkan bahwa pada sambungan dissimilar ini telah terjadi ikatan adhesi pada interface di mana kemungkinan difusi dari tembaga ke dalam baja sudah terjadi mendekati sempurna. 

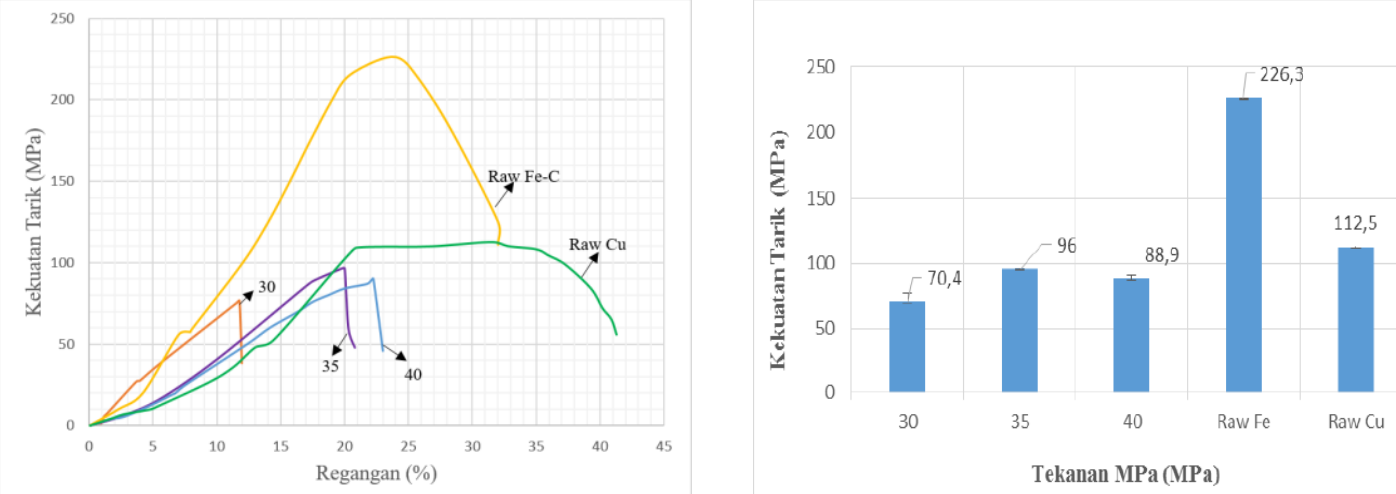

Gambar 3.4 Grafik hubungan kekuatan tarik vs regangan (A), kekuatan tarik pada variasi tekanan gesek $(B)$

Pada tekanan gesek $30 \mathrm{MPa}$, ikatan adhesi yang terbentuk dari dua logam di interface kemungkinan belum tejadi dengan sempurna. Tembaga berdifusi hanya dipermukaan, sehingga kekuatan tariknya masih rendah (70.4 MPa) tersebut (Gambar 3.5 a). Sedangkan pada tekanan yang lebih tinggi, $35 \mathrm{MPa}$ diperoleh kekuatan tarik tertinggi yaitu sebesar 96 $\mathrm{MPa}$. Hal itu menunjukkan bahwa kemungkin terbentuknya ikatan adhesi di interface sudah terjadi seperti dijelaskan di depan dan pada hasil pengamatan struktur mikro sebelumnya. Kekuatan tarik ini mencapai kurang lebih $80 \%$ dari kekuatan tarik dari raw material tembaga yang digunakan. Hasil senada juga disampaikan oleh penelitian terdahulu [10,12]. Apabila tekanan gesek dinaikkan (40 MPa), kekuatan adhesi interface menurun karena naiknya temperatur dan pembentukan intermetallic compound yang lebih banyak dapat menurunkan kekuatan sambungan, $88.9 \mathrm{MPa}[8]$. Secara umum teramati adanya elemen yang terdifusi pada kedua logam yang tersambung dimana deformasi lebih besar terjadi pada material alumunium.

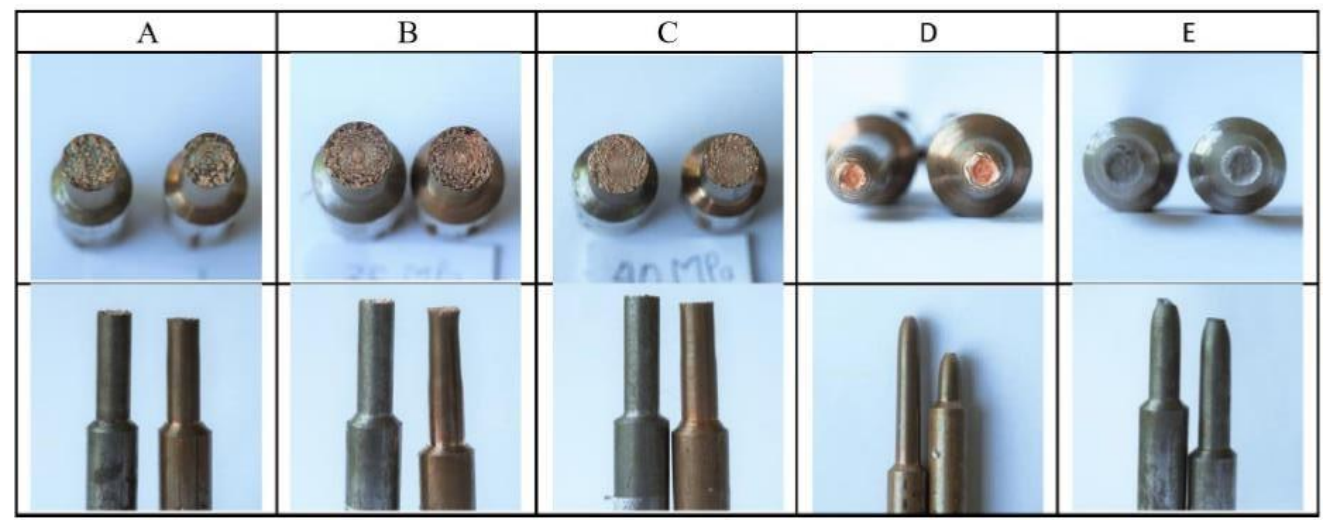

Gambar 3.5 Patahan pengujian tarik sambungan silinder pejal tembaga-baja pada kondisi berbagai kondisi : tekanan gesek $30 \mathrm{MPa}(A), 35 \mathrm{MPa}(B), 40 \mathrm{MPa}(\mathrm{C})$, tembaga (D) dan baja $(E)$

Gambar 3.5 menunjukkan bentuk patahan dari sambungan las gesek dissimilar silinder pejal tembaga-baja. Patahan terdiri dari dua jenis yaitu interface failure (Gambar 3.5(A)) dan mixed mode failure (Gambar (B) dan (C)) (10). Patahan interface terjadi pada sambungan dengan kekuatan dan regangan yang rendah karena difusi antar logam belum banyak terjadi. Sedangkan mixed mode failure terjadi dimana difusi tembaga sudah terjadi lebih banyak dan patah di bagian tembaga. Nilai regangan tertinggi terjadi pada spesimen dengan variasi tekanan gesek $40 \mathrm{MPa}$ sebesar $23 \%$. Hal ini disebabkan karena daerah TMAZ pada tembaga dan baja semakin meluas seiring dengan kenaikan tekanan gesek sehingga regangan yang terjadi menjadi semakin tinggi. Gambar 3.5 menunjukkan patahan dari hasil uji tarik untuk spesimen baja, tembaga dan sambungan dissimilar baja-tembaga masing-masing spesimen dengan variasi tekanan gesek terlihat semua patahan terletak pada sambungan atau pada daerah WCZ tembaga. 


\section{KesimpULAN}

Berdasarkan hasil penelitian pengelasan gesek dissimilar silinder pejal baja-tembaga dengan parameter tekanan gesek $30 \mathrm{MPa}, 35 \mathrm{MPa}, 40 \mathrm{MPa}$ dapat disimpulkan sebagai berikut: kekuatan tarik sambungan dissimilar meningkat seiring dengan meningkatnya tekanan gesek sampai dengan $35 \mathrm{MPa}$ mencapai $80 \%$ kemudian menurun pada tekanan gesek yang lebih tinggi. Dimana semakin tinggi tekanan gesek butiran kecil pada baja semakin meluas didaerah WCZ sampai ke TMAZ. Sementara pada tembaga struktur mikro di daerah HAZ butiran teramati semakin besar seiring dengan bertambahnya variasi tekanan gesek.

\section{Daftar Pustaka}

[1] Li P, Li J, Dong H, Ji C. Metallurgical and mechanical properties of continuous drive friction welded copper/alumina dissimilar joints. Materials \& Design. 2017;127:311-9.

[2] Yazdipour A, Heidarzadeh A. Effect of friction stir welding on microstructure and mechanical properties of dissimilar Al 5083-H321 and 316 L stainless steel alloy joints. Journal of Alloys and Compounds. 2016;680:595-603.

[3] Wei Y, Li J, Xiong J, Huang F, Zhang F, Raza SH. Joining aluminum to titanium alloy by friction stir lap welding with cutting pin. Materials characterization. 2012;71:1-5.

[4] Ohkubo Y, Iwamura S, Hatta $\mathrm{H}$. Thermal analysis on friction welding of carbon steel tube and AA5154 aluminum tube. Sumitomo Light Metal Technical Reports. 2007;48(1):27.

[5] Seli H, Ismail AIM, Rachman E, Ahmad ZA. Mechanical evaluation and thermal modelling of friction welding of mild steel and aluminium. Journal of Materials Processing Technology. 2010;210(9):1209-16.

[6] Fukumoto S, Tsubakino H, Okita K, Aritoshi M, Tomita T. Amorphization by friction welding between 5052 aluminum alloy and 304 stainless steel. Scripta Materialia. 2000;42(8).

[7] Fukumoto S, Tsubakino H, Okita K, Aritoshi M, Tomita T. Friction welding process of 5052 aluminium alloy to 304 stainless steel. Materials Science and Technology. 1999;15(9):1080-6.

[8] Sahin M. Joining of stainless-steel and aluminium materials by friction welding. The International Journal of Advanced Manufacturing Technology. 2009;41(5-6):487-97.

[9] Kusuda Y. Honda develops robotized FSW technology to weld steel and aluminum and applied it to a mass-production vehicle. Industrial Robot: An International Journal. 2013.

[10] Kimura M, Kusaka M, Kaizu K, Fuji A. Effect of friction welding condition on joining phenomena and tensile strength of friction welded joint between pure copper and low carbon steel. Journal of Solid Mechanics and Materials Engineering. 2009;3(2):187-98.

[11] Jayabharath K, Ashfaq M, Venugopal P, Achar D. Investigations on the continuous drive friction welding of sintered powder metallurgical $(\mathrm{P} / \mathrm{M})$ steel and wrought copper parts. Materials Science and Engineering: A. 2007;454:114-23.

[12] Wei $\mathrm{Y}$, Sun F. Microstructures and mechanical properties of $\mathrm{Al} / \mathrm{Fe}$ and $\mathrm{Cu} / \mathrm{Fe}$ joints by continuous drive friction welding. Advances in Materials Science and Engineering. 2018;2018.

[13] Kurt A, Uygur I, Paylasan U. Effect of friction welding parameters on mechanical and microstructural properties of dissimilar AISI 1010-ASTM B22 joints. Welding journal. 2011;90(5):102-6.

[14] Luo J, Xiang J, Liu D, Li F, Xue K. Radial friction welding interface between brass and high carbon steel. Journal of Materials Processing Technology. 2012;212(2):385-92.

[15] Wang Y, Luo J, Wang X, Xu X. Interfacial characterization of T3 copper/35CrMnSi steel dissimilar metal joints by inertia radial friction welding. The International Journal of Advanced Manufacturing Technology. 2013;68(5-8):1479-90.

[16] Vairamani G, Kumar TS, Malarvizhi S, Balasubramanian V. Application of response surface methodology to maximize tensile strength and minimize interface hardness of friction welded dissimilar joints of austenitic stainless steel and copper alloy. Transactions of Nonferrous Metals Society of China. 2013;23(8):2250-9. 